The World of Piers Plowman 


\section{The Middle Ages Series \\ Ruth Mazo Karras, Series Editor Edward Peters, Founding Editor}

A complete list of books in the series is available from the publisher. 


\title{
The World of
}

\section{Piers Plowman}

\author{
Edited by \\ Jeanne Krochalis \\ and \\ Edward Peters
}

\section{$\overline{\text { PENN }}$}

University of Pennsylvania Press

Philadelphia 
Copyright (C) 1982 University of Pennsylvania Press

All rights reserved

Printed in the United States of America on acid-free paper

10988765543321

Published by

University of Pennsylvania Press

Philadelphia, Pennsylvania 19104-4112

Library of Congress Cataloging-in-Publication Data

The world of Piers Plowman / edited by Jeanne Krochalis and Edward Peters.

p. cm. - (The Middle Ages series)

ISBN-13: 978-0-8122-1085-9 (pbk.: alk. paper)

ISBN-10: 0-8122-1085-9 (pbk.: alk. paper)

1. Langland, William, 1330?-1400? Piers the Plowman. 2. English literature-

Middle English, 1100-1500. 3. Manners and customs in literature. 4. England-Social life and customs-1066-1485. I. Series. II. Krochalis, Jeanne. III. Peters, Edward H. PR2015.W6

821 '.1 
To

Morton W. Bloomfield

and

E. Talbot Donaldson

Magistris nostris 
